\title{
COSTUMBRES SEVILLANAS OLVIDADAS: LAS PROCESIONES EN HONOR A MARÍA POR DONCELLAS EN LA CASA DE MISERICORDIA DE SEVILLA EN EL ANTIGUO RÉGIMEN*
}

\author{
SEVILLAN CUSTOMS FORGOTTEN: \\ THE PROCESSIONS IN HONOR OF MARY BY MAIDENS \\ IN THE CASA DE MISERICORDIA DE SEVILLA IN THE OLD REGIME
}

\author{
COSTUMES SEVILHANOS ESQUECIDOS: \\ AS PROCISSOES EM HOMENAGEM A MARIA POR DONZELAS \\ NA CASA DE MISERICORDIA DE SEVILLA NO REGIME ANTIGO
}

\author{
PAULA ERMILA RIVASPLATA VARILLAS ${ }^{* *}$ \\ Universidad Nacional Mayor de San Marcos (Perú) \\ DOI: https://doi.org/10.46553/EHE.22.1.2020.p53-79
}

\begin{abstract}
Resumen
La ciudad de Sevilla se caracterizó por la ferviente animosidad en sus manifestaciones religiosas. Fe y pomposidad estaban confundidas en las fiestas religiosas y era lo que la caracterizaba, llegando a rivalizar entre sí las instituciones para ofrecer las más fastuosas y reconocidas de la capital hispalense. La necesidad de hacer notar su religiosidad en la colectividad hizo que la ciudad se acostumbrara a una notoria manifestación religiosa pública que contrastaba con las manifestaciones de otros lares, especialmente con las del norte de la península ibérica. El caso presentado trata de unas fiestas religiosas, impuestas por voluntad testamentaria para la realización de una festividad por la virginidad, ensalzando a María, a través de una procesión de vírgenes, aunque también el hospital realizaba una procesión por el sacramento, enalteciendo a Jesús a través de sus representantes los curas.
\end{abstract}

Palabras clave

Fiestas - procesiones - Sevilla - Antiguo Régimen

\begin{abstract}
The city of Seville was characterized by fervent animosity in its religious manifestations. Fe and pomposity were confused in the religious festivals and it was what characterized her, coming to rival the institutions among themselves to do the most recognized in Seville capital. The need to make their religiosity felt in the community made the city get accustomed to a notorious public

\footnotetext{
* Fecha de recepción del artículo: 2/5/19. Fecha de aceptación: 30/3/2020.

** Investigadora RENACYT. Orcid: https://orcid.org/0000-0001-7036-6436. Dirección postal: Calle Bilbao 119, distrito Pueblo Libre, Lima, Perú, e-mail: rivasplatavarillas@gmail.com
} 
religious manifestation that contrasted with the manifestations of other places, especially those of the north of the Iberian Peninsula. The case presented deals with religious festivals, imposed by will testamentary to the realization of a festival for the virginity, extolling Mary, through a procession of virgins, but also the hospital made a procession for the sacrament, praising Jesus. through their representatives the priests

\section{Key words}

Parties - Processions - Sevilla - Old Regime

\section{Resumo}

A cidade de Sevilha caracterizou-se pela fervorosa animosidade em suas manifestações religiosas. Fé e pompa foram confundidos nos festivais religiosos e foi o que a caracterizou, chegando a rivalizar-se mutuamente com instituições para oferecer a mais pródiga e reconhecida da capital de Sevilha. A necessidade de fazer sentir sua religiosidade na comunidade fez com que a cidade se acostumasse a uma notória manifestação religiosa pública que contrastava com as manifestações de outros Lares, especialmente os do norte da Península Ibérica. O caso apresentado trata de festas religiosas, impostas pelo testamento à realização de um festival para a virgindade, exaltando Maria, através de uma procissão de virgens, mas também o hospital fez uma procissão pelo sacramento, louvando Jesus a através de seus representantes os sacerdotes.

\section{Palavras-chave}

Festas - procissões - Sevilla - Antigo Regime

Este trabajo se ha realizado utilizando información documental del Archivo Histórico Provincial de Sevilla(AHPS), del Archivo de la Diputación Provincial de Sevilla (ADPS) y del Archivo General de Indias (AGI), consultando además la información bibliográfica proveniente de la Biblioteca Colombina, el Fondo Histórico de la Universidad de Sevilla y la Biblioteca del Instituto de Estudios Hispanoamericanos. La metodología utilizada pasó por un proceso de búsqueda en los repositorios mencionados, donde se consultó la documentación primaria y secundaria que se correlacionó e interpretó.

El objetivo de este artículo fue rescatar y conocer unas procesiones sevillanas del Antiguo Régimen olvidadas, en las que se enaltecía la sacrificada labor de los sacerdotes pobres y la virginidad y buena fama de las jóvenes, reconociéndolas públicamente, para que sirviesen de ejemplo a la colectividad. Pero, este artículo también trata del problema cada vez más apremiante que era conseguir que las mujeres pobres lograran casarse en el mercado matrimonial, ofreciéndoles dotes para conseguir marido. Muchas no lograban casarse, por lo que a pesar de haber ganado una dote no conseguían hacerla efectiva a pesar que al desfilar en una especie de escaparate, exhibían públicamente que eran mujeres que había logrado una dote por ser virtuosas. Dinero y honra, señuelos considerados perfectos para conseguir marido, ya no eran suficientes a medida que avanzaban los años en la Edad Moderna.

La hipótesis de esta investigación considera que estas prácticas procesionales religiosas barrocas que premiaban la virtud y la castidad, fundadas por personas pías que crearon patronatos en la Casa de Misericordia para recordar sus memorias y rezar por sus almas, como el de Alonso de Montalbán, incentivaron en la colectividad 
sevillana el matrimonio público, uno de los objetivos trazados en el Concilio de Trento. El fin fue disminuir el matrimonio clandestino y prácticas de convivencia como el amancebamiento, la barraganía y las libres relaciones prematrimoniales.

En el Antiguo Régimen español, festividades religiosas y laicas se repetían año tras año, dibujando en el paisaje sevillano del Antiguo Régimen, peculiaridades visuales, auditivas, olfativas y sensitivas que caracterizaron a la capital andaluza. En Sevilla, las procesiones se celebraban por doquier, eran los gestos colectivos barrocos del siglo XVII, por excelencia. ${ }^{1}$ Estos actos litúrgicos píos, también, servían para comunicar al público necesidades a satisfacer como encontrar esposo, padres adoptivos o quizá donantes, en el mejor de los casos. Por ejemplo, había una casa de acogida de recién nacidos cerca de la Catedral hispalense, para la que se instituyó un fondo perpetuo al cuidado de ciento cuarenta expósitos al año. ${ }^{2}$ Eran tantos que los canónigos de la Catedral en la procesión de la Fiesta de la Anunciación los ofrecían al público, desfilando en brazos de sus niñeras. De esta manera, muchos bebes encontraban padres adoptivos, los demás eran enviados a los orfanatos de la ciudad. ${ }^{3}$ Las instituciones hospitalarias no fueron la excepción y realizaban numerosos fiestas religiosas con la activa participación del pueblo. Uno de los más importantes hospitales sevillanos de la Edad Moderna, el Hospital de la Sangre, celebró fastuosamente su traslado del barrio de Santa Catalina, dentro de las murallas de la ciudad, a extramuros en el barrio de la Macarena, a través de una procesión solemne, grandilocuente y bulliciosa, saliendo del antiguo hospital hacia el nuevo a mediados del siglo XVI. Asimismo, la fiesta principal de este hospital era la de Quasimodo, que congregaba a todos los trabajadores del hospital a los que se pasaba lista previa amenaza de castigo monetario en sus salarios, si es que no asistían. La población estaba invitada a participar en dicha fiesta donde el principal actor era el prior del monacato que tuviese la jefatura del priorato de aquella institución con una ceremonia especial, cargada de simbolismos, ante el altar mayor de la iglesia del Hospital de la Sangre. ${ }^{4}$ La dirección de este hospital estaba a cargo de los priores de tres monasterios sevillanos: Santa María de las Cuevas, San Jerónimo de Buenavista y San Isidoro del Campo, los que se turnaban anualmente en la jefatura y en su representación pública en las principales celebraciones religiosas.

También hay que tener en cuenta que en el siglo XVI, la Iglesia en Castilla consolidó su posición predominante, dirigiendo, controlando las vidas y conciencias de sus feligreses y normalizando el conjunto de sus actos, principalmente después del Concilio de Trento (1545-1563), a tal grado que el matrimonio se convirtió en un sacramento de obligado cumplimiento religioso y civil desde el reinado de Felipe II, reforzando una estrecha relación entre el poder civil y el eclesiástico. ${ }^{5}$ Además, la Contrarreforma se propuso corregir y moldear a la mujer a través de un modelo a imitar, la virgen María, que encarnaba la humildad, pureza y virginidad, como una

\footnotetext{
${ }^{1}$ GARCÍA BERNAL, 2006, p. 267; ESCALERA PÉREZ, 2011, pp. 273-285.

${ }^{2}$ GIMÉNEZ MUÑOZ, 2006, p. 13. Casa de Expósitos fundada por el arzobispo de Sevilla Fernando Valdés en 1558.

${ }^{3}$ PERRY, 2012, p.154.

${ }^{4}$ ADPS, Libro de capellanías del hospital de la Sangre de Sevilla (1692-1709), leg.183, f.11r.

${ }^{5}$ ORTEGA LÓPEZ, 1997, pp. 249-344.
} 
contraposición a Eva que representaba el pecado. ${ }^{6}$ De esta manera, los estamentos privilegiados fomentaron medidas para favorecer los matrimonios, creándose numerosos patronatos entregados para que lo dirigieran instituciones pías para dotar a doncellas pobres a tomar estado de casadas para fomentar la popularidad del sacramento entre las masas y, así, ayudar a la iglesia en la salvación de sus almas.

En el periodo barroco se hizo imprescindible y popular la dote para contraer matrimonio. Si bien es cierto que las dotes de doncellas se entregaban desde antes del mencionado Concilio de Trento, se incrementaron visiblemente a raíz de éste desde finales del XVI, alcanzando su cenit en el siglo XVII. El descenso fue en los siglos XVIII y XIX, tal como lo comprueba en el caso estudiado en este trabajo.

La institución que nos ocupa en este artículo era conocido popularmente como el Hospital de la Misericordia, pero no cumplía tal papel sino que era una casa pía encargada de la distribución de las donaciones testamentarias que le llegaban de distintas partes de la Península Ibérica y de las Indias. Los legados testamentarios, que creaban patronatos, estaban destinados en primer término para crear capellanías, a fin de realizar misas por el alma de los donantes. ${ }^{7}$ Acto seguido, los donantes pedían el cumplimiento de las obras pías que deseaban apoyar, para lo cual dejaban patrimonio en bienes inmuebles con cuyas rentas las mantenían. De la idónea administración de estas rentas dependía la permanencia de la obra pía. El principal objetivo por el que fue creado este "hospital" fue para dotar a jóvenes pobres y huérfanas a matrimonio, por lo que el grueso de donaciones iba a cumplir este destino. El modo de entregarlo era lo que distinguía un patronato de otro. La mayoría de los testamentos indicaban los beneficiarios de los legados, la cantidad entregada, la frecuencia y quien lo otorgaría. Pero, algunos testamentos claramente indicaban cómo debían ser entregados las dotes y, entre todas, destacaba la dotación de Alonso de Montalbán, que con dinero obtenido en las Indias españolas, inauguró una procesión de doncellas vírgenes en el día de la celebración del Dulce Nombre de María en la iglesia del Hospital de la Misericordia de Sevilla. ${ }^{8}$ El requisito fundamental para recibir la dote para tomar estado de casada era ser pobre, tener buena fama entre la colectividad para que mereciera recibir tal regalo. El testamento de Montalbán indicaba detalladamente cómo quería que fuesen entregadas las dotes, es decir, tal cual lo hacía la capilla de las doncellas de la Catedral de Sevilla, previa ceremonia pública. De esta manera, el patronato de Alonso de Montalbán inauguró una procesión de vírgenes, nombradas a una dote de matrimonio, condición previa y fundamental para recibirla. También este patronato legó una

\footnotetext{
${ }^{6}$ BIRRIEL SALCEDO, 2012, p. 173; CUÉLLAR ARRABALÍN, 1990, p. 243; MÁRQUEZ DE LA PLATA Y FERRÁNDIZ, 2005, p. 205. El éxito de la Concepción fue mayor entre las mujeres que en los varones, pues lograban un doble reconocimiento como madres y como solteras.

${ }^{7}$ TIENZA LÓPEZ, 2008, pp. 79-80. El concepto de patrono se refiera a protección y amparo, pero también de poder relacionadas con la nobleza.

8 AGI, CONTRATACION, 964B, N.2, R.17, 1639. Bienes de difuntos y testamento. Alonso de Montalbán fue vecino de Sevilla, casado con Josefa de Zúñiga y Narváez, falleció en Madrid, dejando un testamento. Sus albaceas fueron su esposa y el procurador mayor de la Casa de la Misericordia de Sevilla; Pedro Carrillo de Guzmán y Leonardo de la Cueva, dejando todos sus bienes a la Casa de la Misericordia de Sevilla.
} 
cantidad anual para realizar otra procesión de sacerdotes pobres el día del Santísimo Sacramento en la iglesia del hospital estudiado con toda la pompa debida e indicada.

\section{Fundación y administración de la Casa de Misericordia de Sevilla}

Según la leyenda, a fines del siglo XV, a Antón Ruiz, clérigo capellán de don Pedro Enríquez, Adelantado Mayor de Andalucía y Señor de Tarifa, se le apareció dos veces el arzobispo sevillano San Isidoro, vestido de pontifical con mitra y báculo, y le dijo que "procurase por las pobres de Jesucristo para las huérfanas doncellas pobres para ayuda de sus casamientos". 9 Esta alegoría estaría conectada con la relación estrecha de los obispos de dotar doncellas en la Edad Media. ${ }^{10}$ Antón Ruiz y Juan Rodríguez de Torres, notario apostólico, presbítero y capellán perpetuo de la iglesia de "Omnium Sanctorum" de Sevilla, hicieron participe de este objetivo al provisor del arzobispado de Sevilla Pedro de Solís, en ausencia del cardenal arzobispo de Sevilla Pedro González de Mendoza, que les dio licencia para pedir limosna. ${ }^{11}$

La cofradía para casar doncellas pobres y huérfanas la fundó Antón Ruiz junto a otros cofrades en 1476. El objetivo primordial de este hospital fue dotar para casamiento a doncellas pobres y/o huérfanas desamparadas. Su regla indica que fue para: "Honra de la Virginidad, para socorro y casamiento de doncellas pobres huérfanas y otras obras pías...considerando la fragilidad humana y el riesgo que corren las doncellas pobres y huérfanas y cuan gran misericordia y servicio de Dios, es ponerlas en estado de casadas y cumplir las obras pías que las personas cristianas, movidas con su santa intención en sus testamentos y fuera de ellos nos han encomendado". ${ }^{12}$

La Casa de Misericordia de Sevilla recibía donaciones testamentarias de diferentes partes del mundo, especialmente de los lugares pertenecientes a la Monarquía Hispánica para dotar a doncellas pobres, pero también para otras obras pías, según voluntad delegada. Sin embargo, algunas dotaciones le daban libertad a la Misericordia para destinar dinero a lo que considerase necesario. La administración de esta institución estaba dirigida por una hermandad cuyos miembros pertenecían a la élite local sevillana. Sus miembros, como a las personas que ayudaban, eran seleccionados por su fama y buen nombre, premiando los que seguían la doctrina cristiana, en el marco de la Contrarreforma. Se recompensaba al que lo merecía y esto servía de emulación para el resto de la sociedad. Los miembros de la hermandad de la Misericordia en comisiones de trabajo realizaban listas de las personas que se presentaban a las convocatorias públicas anuales que la institución realizaba para entregar limosnas, a los que visitaban y confirmaban su estado, tipo de vida y fama para confirmar si debían recibir una limosna u obra pía. Otros pobres eran presentados por los propios hermanos, teniendo su aval o garantía, que eran personas que merecían

\footnotetext{
${ }^{9}$ AHPS, Libro capitular 4739, (1568-1590), 14/11/1584. Relación de la casa y hospital de la misericordia de esta ciudad de Sevilla en la colación de San Andrés.

${ }^{10}$ LATORRE CIRIA, 2015, pp.183-210.

${ }^{11}$ ALBARDONEDO FREIRE, 2003, p. 69.

${ }^{12}$ CONGREGACIÓN DE LA CASA DE LA MISERICORDIA, 1599, s/f.
} 
ser ayudadas. Esta casa pía seguía las catorces misericordias, las corporales (visuales) y las espirituales (internas). Entre las corporales estaban dar de comer al hambriento y beber al sediento, dar techo a quien no lo tenía, vestir al desnudo, visitar a los enfermos y a los presos y enterrar a los muertos. Entre las espirituales estaban las de rezar por los vivos y los muertos, enseñar al que no sabía, aconsejar, consolar, rezar, corregir, perdonar y sufrir con paciencia.

Los miembros de la Casa de Misericordia de Sevilla cumplían con estos preceptos y otros como las celebraciones de fiestas anuales a la Virgen María y el impulso a la formación de patronatos de ayuda al prójimo, incentivados aún más desde el Concilio de Trento. Las fiestas procesionales estudiadas en este artículo estaban dirigidas a enseñar al pueblo con el ejemplo el premio que recibían los que realizaban sus deberes morales y religiosos y llevaban una vida honrada, coronada por la buena fama.

Es interesante indicar que otras casas de la Misericordia estaban presentes en diferentes reinos, cumpliendo similares funciones de caridad, pero no iguales. Las Misericordias tenían similitudes, pero también diferencias en sus actividades. Estas instituciones compartían procesiones como las de los muertos, en el que recogían los huesos de ajusticiados para darles sepultura, generalmente el Día de Todos los Santos y las procesiones de Semana Santa. ${ }^{13}$ También, tenían sus particularidades como la procesión de jóvenes dotadas por la Misericordia en Sevilla, que consistía en la exposición pública de vírgenes casamenteras que por su buena fama habían sido merecedoras de una dote y ajuar, entregados por la institución. De esta manera, las Misericordias de Sevilla y las del Reino de Portugal celebraban la muerte y el acceso a una "nueva vida" en el cielo, pero también se aclamaba la vida y la generación de la misma en la tierra, en el caso sevillano donde ya era costumbre por algunas instituciones hacer desfilar a sus vírgenes dotadas.

\section{Procesiones realizadas en la Casa de Misericordia de Sevilla}

\section{1.-Procesion de difuntos de la Casa de Misericordia de Sevilla}

$\mathrm{Si}$ bien las procesiones estudiadas fueron impuestas por una voluntad testamentaria particular, esta casa pía practicaba desde su creación procesiones de difuntos, las más fastuosas eran las de sus hermanos fallecidos, pues el acto de la muerte y el sucesivo entierro debía ser un acto público y de acompañamiento en el Antiguo Régimen. ${ }^{14}$

La procesión de difuntos en la Casa de Misericordia de Sevilla, la más antigua de la hermandad, implantada desde su fundación en el siglo XV, se desarrolló de tal forma que a fines del siglo XVI, la encontramos con una parafernalia muy bien montada y organizada. Esta procesión estaba conformada por doce clérigos capellanes, elegidos por el padre mayor, los cuales realizaban los actos litúrgicos en las fiestas religiosas y

${ }^{13}$ LOBO DE ARAÚJO, 2006, p.156.

${ }^{14}$ RIVASPLATA VARILLAS, 2014, p. 84. 
en los entierros que el hospital tenía obligación de hacer. Uno de ellos era el guía y el resto le obedecía. La presencia de estos clérigos era fundamental durante el entierro de algún hermano y de los que la Casa de Misericordia tenía obligación de sepultar y acompañar. Los doce juntos con sobrepellices partían de la Misericordia, acompañando un gran crucifijo en dos filas, precedidos por dos niños huérfanos de la Casa de la Doctrina Cristiana con dos hachas de cera. Todos juntos iban a la casa del difunto para desde allí, llevarlo a enterrar a la iglesia o monasterio escogido por el difunto. Todos debían estar presentes en la misa y vigilia realizados por los doce clérigos. Acabado el entierro, regresaban todos juntos en procesión a la Misericordia, acompañando al crucifijo. Al llegar decían una oración y responso. Cada uno de los doce clérigos recibía dos reales por este trabajo. ${ }^{15}$ También eran convocados a las fiestas que la Misericordia tenía obligación de realizar. Llegaban a vísperas antes del primer salmo y el siguiente día participaban de la fiesta, misa y sermón, recibiendo dos reales cada uno. El capellán principal debía entregar a tiempo a estos clérigos el vestuario que usarían en las fiestas. Aquella persona que no tenía causa justificada para no cumplir su labor, era despedida y reemplazada por otra. La participación de estos capellanes era fundamental cuando un hermano enfermaba. Ante la probable muerte, al enfermo se le ponía una sobrepelliz y era custodiado por dos clérigos en el día y otros dos en la noche, rezando salmos y devociones. Estos clérigos eran cuatro de los doce que tenía la Misericordia o los que el padre mayor invitara. Esta medida continuaba hasta que el hermano falleciera o estuviese mejor. El mayordomo les pagaba. En caso de fallecimiento, un muñidor o intermediario llamaba a los hermanos para que estuviesen presentes en el entierro de uno de ellos con velas que el casero les entregaba. Les mandaban decir veintiocho misas rezadas y dos cantadas con sus responsos. Eso mismo se hacía para sus esposas.

Si un hermano fallecía estando a cinco leguas de Sevilla se le mandaba traer a la Misericordia siendo recibido en las puertas de la ciudad con las teas encendidas, acompañándolo hasta que fuese enterrado en alguna iglesia o monasterio. Si era enterrado fuera de la ciudad se le acompañaba hasta la puerta de la ciudad. Los hermanos debían rezar veinte veces el Padre Nuestro y el Ave María al ánima del difunto. También la Misericordia enterraba a los padres, parientes, hijos e hijas solteros que viviesen en la casa paterna del hermano difunto, diciéndoles una misa cantada y cinco rezadas. Si las mujeres de los hermanos se volvían a casar, la Misericordia ya no se ocupaba de sus entierros, pues salían de la órbita de su responsabilidad. ${ }^{16}$

En caso que un hermano no pudiese asistir a estos entierros, debía pedir licencia al padre mayor; si no, pagaba una multa de un real. Los hermanos que fueran llamados para los entierros de sus análogos y no vinieran, entonces debían pagar cuatro reales, por los hijos dos reales y por los demás parientes uno. El hermano desterrado de la ciudad sería enterrado como cualquier otro cofrade.

\footnotetext{
${ }^{15}$ CONGREGACIÓN DE LA MISERICORDIA, 1622, f.54v-f.55r. Para celebrar las fiestas y acompañar entierros de hermanos y testadores había doce clérigos que nombraba el padre mayor, acudían a las vísperas, misas, fiestas y entierros. Al fallecer el padre mayor recibía 100 misas, un hermano y su esposa 50 misas. Los hijos e hijas, padres de los testadores se podían enterrar en la iglesia haciéndoles 6 misas.

${ }^{16}$ Ibídem, f.55v-f.56r.
} 
A cualquier persona que dejase bienes al hospital de 100 ducados para arriba se le enterraba realizando seis misas, acompañado por doce clérigos y crucifijo. Los legos eran enterrados con acompañamiento de sacristanes y los clérigos por sus homólogos en la iglesia del hospital. El sentimiento de pertenencia y unión era desarrollado y fortalecido a través de estas ceremonias entre los hermanos de la Misericordia que les daba prestigio, poder, estima y admiración en la comunidad. ${ }^{17}$

\subsection{Fiesta del Santísimo Sacramento}

Esta celebración tuvo largos periodos de ausencia como a finales del siglo XVII y mediados del siglo XVIII. La documentación indica que estuvo suspendida por varios años antes de 1733 por falta de rentas necesarias para realizarlo. Esta fiesta se debía realizar el jueves primero después de la octava del Corpus o el domingo siguiente con vísperas. ${ }^{18}$ El día siguiente de aquella festividad debía estar descubierto el Santísimo Sacramento hasta que acabaran los oficios, cerrándose con el adorno y cera necesaria. Esta conmemoración debía tener sermón, órganos o chirimías, música de clarines, además de una procesión por la iglesia, asistiendo en ella el padre mayor y los hermanos de la Misericordia, dando a cada uno una vela de dos libras de cera. Ese día debían festejar a dieciocho sacerdotes pobres naturales de la ciudad, vistiéndolos o más si diese la renta y que los nombrase el cabildo por votos con preferencia siempre a los más pobres y ancianos porque su intención era ayudarlos. La convocatoria se hacía a través de edictos en las parroquias de la ciudad de Sevilla, dándoles a cada uno de los elegidos para que llevaran puestos una sotana, manto, sombrero, bonete y una vela de media libra que llevaran encendidas en la procesión y un escudo del Santísimo Sacramento, el que acabada la procesión lo debía devolver. Asimismo, daban a cada uno 100 reales para que arreglaran su vestido. Todos debían oficiar misa al día siguiente de la procesión en la iglesia de la Casa de Misericordia, excepto los que estuviesen impedidos. ${ }^{19}$ Los sacerdotes debían recoger las medallas, asistir a la fiesta de la parroquia, engalanada con música, clarinero, alumbrada con velas, y mucha algarabía ruidosa procedente de cohetes de mano y ruedas. La iglesia invitaba a la población a participar de esta fiesta.

En esta celebración como en la de las doncellas, la Casa de Misericordia tampoco se cumplía con la voluntad del testador en cuanto a elegir a los sacerdotes más pobres de la ciudad que libremente se presentaran en la convocatoria pública, sino que eran elegidos por los hermanos de la Casa. Esta irregularidad como otras, los hermanos trataban de enmendar cada cierto tiempo en sus reuniones capitulares.

"cometiéndolo a los hermanos que por turno les había tocado y para su aprobación se remitían a la junta secreta y por no ser conforme a lo expresado en la cláusula de dicha fiesta sino que hubiesen de preceder edictos que se pusiesen en las parroquias de Sevilla para que se opusiese en el cabildo de esta casa quien los ha de nombrar prefiriendo a los

\footnotetext{
${ }^{17}$ LOBO DE ARAÚJO, 2010, p.114.

18 AHPS, Libro cabildo 4762(1741-1746) 06/05/1742. En 1742, la fiesta del sacramento se celebró el domingo después de la octava del corpus, vistiéndose a 18 sacerdotes.

${ }^{19}$ AHPS, Libro cabildo 4761 (1736-1741) 03/06/1740 f. 278 r-v, 279r.
} 
más pobres y ancianos se acordó el que no se hagan los nombramientos en particular por los hermanos como se había estilado sino juntos en el cabildo". ${ }^{20}$

Aquella fiesta estuvo suspendida muchos años desde 1704 hasta 1733 cuando habiendo caudal, el cabildo determinó ejecutar, encomendando a una comisión de hermanos vestir 18 sacerdotes con sotana, mantel de bayeta, sombrero y mangas de paño en lugar de bonete, entregándoles 100 reales a cada uno. La misa comprendía sermón por el cual el sacerdote que la oficiaba recibía 24 reales; además, se tocaba órgano y chirimías y se traía música del colegial de Nuestro Señor San Salvador, o bien, de la Catedral, lo que costaba una limosna de 16 pesos, aunque luego se redujo el precio a 5 porque se anuló lo de la Catedral en 1733, cuando, también, se redujo el vestuario de los curas prestándoles el bonete y la medalla que llevaban puesta con la insignia del Santo Sacramento, aunque continuó dándose los 100 reales y la vela de media libra así como el mismo número de capellanes que asistían a dicha fiesta. En cuanto al adorno de la iglesia, solo se utilizaría una colgadura sin tribunas por ser muy costoso, ni tampoco se adornó la capilla mayor y los demás gastos de fuegos artificiales serían reducidos. Los hermanos de la Misericordia asistían con velas de a dos libras que llevaban sus hijos para que hubiese más gente en la función, debido al poco número de los hermanos que había, por lo que la dotación de 30 velas de dos libras continuó. En 1733, el cabildo regulo la fiesta del Sacramento porque no se cumplía conforme a la voluntad del testador y no había dinero respecto a lo que antes se gastaba.

\subsection{Fiesta de procesión de vírgenes en Sevilla}

La fiesta de exaltación doctrinal dirigida a la Inmaculada nació en Andalucía, específicamente en Sevilla y Granada entre 1615 a 1620, se celebraban en gremios, colegios, cofradías, corporaciones y fiestas particulares. ${ }^{21} \mathrm{Si}$ bien, fiestas en honor a la Virgen María fueron realizadas desde antes de aquellas fechas. Así, las encontramos en la hermandad de las Doncellas de la Capilla de la Anunciación de la Virgen María o de las doncellas de la Catedral de Sevilla, la que había sido fundada en 1521 por Micer García de Gibraleón, protonotario y escritor apostólico en la corte romana, y Diego López de Cortegana, arcediano de Sevilla. Esta hermandad estuvo conformada por seiscientas parejas de esposos. Los cofrades pertenecían a la alta nobleza y a los pequeños linajes nobiliarios sevillanos, relacionados con el Cabildo de la ciudad. ${ }^{22} \mathrm{La}$ Capilla de la Anunciación, que llamaban de las doncellas, está localizada en la Catedral sevillana. Estaba dotada de una generosa renta con el fin de casar doncellas pobres anualmente, a la que se sumaron otros legados testamentarios, de tal manera que lograron casar al año treinta y cuatro doncellas con la anuencia de sus priores y consejeros.

\footnotetext{
${ }^{20}$ AHPS, Libro cabildo 4762 (1741-1746) 01/07/1742.

${ }^{21}$ GARCÍA BERNAL, 2006, pp.281-283.

22 MORELL PEGUERO, 1986, pp. 174 y 175. Según la autora, los cofrades de la Capilla de las Doncellas pertenecían a una hermandad de carácter abierto, que se encontrarían en una zona intermedia entre la aristocracia legalmente constituida y el estamento llano.
} 
En Sevilla, otras hermandades e instituciones pías realizaban procesiones de vírgenes dotadas para matrimonio, como el caso de la cofradía de la Santa Vera Cruz de Sevilla, que fue fundada en 1448, siendo su fin principal la dotación de doncellas para tomar estado de casadas o de religiosas que lo cumplió hasta 1832. Los hermanos de la cofradía elegían y nombraban a las doncellas dotadas en los meses de abril y noviembre, las cuales salían en procesión el día de la fiesta de la Santa Cruz (3 de mayo) y el día de la fiesta de la Limpia Concepción de María ( 8 de diciembre). Posteriormente a dicho acto, la doncella se podía casar y velar, avisando a la hermandad para que enviara a dos diputados, quienes, en dicho acto, le entregaría la dote. Así, se realizaba el nombramiento y la entrega de dotes dos veces al año. La elección de las doncellas nombradas a la dote se hacía por sorteo o bien designadas por los oficiales, siendo una dotación de doncellas pobres de carácter abierto, al admitir a cualquiera de ellas participar en el reparto de dotes. ${ }^{23}$ Ambas opciones -designación y suertes- fueron válidas desde 1599 hasta 1613, cuando la institución estableció nombrar a las afortunadas a dotes entre las parientas de hermanos de la cofradía, convirtiéndose en una dotación de doncellas pobres de índole cerrada.

\section{Las fiestas del patronato de Alonso de Montalbán en la Casa de Misericordia de Sevilla}

Alonso de Montalbán dejó un testamento cerrado que otorgó al escribano Francisco López Castellar en Sevilla el 16 de octubre de 1637. Al fallecer su testamento fue abierto ante el mismo escribano el 25 de octubre de 1638, por el cual fundaba un patronato que se ocuparía de una capellanía, el cumplimiento de fiestas religiosas y para la ejecución de diferentes obras pías en la Casa de Misericordia de Sevilla.

Montalbán fue vecino de Sevilla, casado con Josefa de Zúñiga y Narváez y falleció en Madrid, dejando un testamento. Sus albaceas fueron su esposa y el procurador mayor de la Casa de la Misericordia de Sevilla, Pedro Carrillo de Guzmán y Leonardo de la Cueva, dejando todos sus bienes a la mencionada casa pía. Montalbán fundó un patronato de diferentes obras pías, fiestas y capellanías, entre las cuales estaba la entrega de dotes a huérfanas, mantenido a través del residuo que quedase de la renta de sus fincas y de dinero proveniente de las Indias. Las rentas de los bienes de Montalbán eran repartidos en cuatro partes. La primera era destinada para fiestas y capellanías realizadas anualmente. La segunda utilizada en presos y cautivos. La tercera y cuarta parte del residuo que quedaba era dividida por iguales partes, la mitad para la festividad del Sacro Misterio de la Eucaristía, para la compra del vestuario de los dieciocho sacerdotes y la otra mitad a la festividad del Dulcísimo Nombre de María Santísima con el vestuario y dotes de dieciocho doncellas. La cantidad dependía de la renta anual del patronato. Si sobraba algún caudal de ambas festividades, el fundador indicó que se distribuyese en festividades y vestuarios.

\footnotetext{
${ }^{23}$ HERMANDAD DE LA ANUNCIACIÓN DE NUESTRA SEÑORA DE SEVILLA, 1715, pp. 1-108.
} 


\subsection{La fiesta del Dulcísimo nombre de María con procesión de doncellas vírgenes}

El 25 de octubre de 1638, Alonso de Montalbán fundó un patronato que dotaba anualmente a doncellas pobres sevillanas a dotes matrimoniales, las nombradas debían realizar una procesión en la Iglesia de la Casa de Misericordia de Sevilla. Su testamento claramente indicaba este deseo de dotar a jóvenes pobres para tomar estado de matrimonio. $^{24}$ Las doncellas recibirían una dote si previamente participaban en una ceremonia procesional dedicada a la Virgen María. Se trataba de la fiesta del Dulcísimo Nombre de María que se celebraba en diferentes partes de España, habiéndose realizado desde antes de 1513, siendo la primera registrada en Cuenca. Fiesta popular de raíz española que en la Casa de Misericordia de Sevilla se empezó a realizar a mediados del siglo XVII e incluía procesión de dieciocho doncellas dotadas y nombradas que dispuso el fundador del patronato, Alonso de Montalbán. Esta procesión se celebró hasta fines del siglo XVIII.

La primera fiesta de doncellas que registra este patronato fue en 1640, de acuerdo al cabildo del 18 de enero de aquel año donde se dijo la forma con que se había de celebrar y nombrar a las doncellas, las que serían convocadas a través de edictos públicos, nombradas por los hermanos. Pero, el 1 de julio de aquel año el cabildo acordó proponer a las doncellas huérfanas y pobres a los hermanos por su antigüedad, habiendo ganado su asistencia el año antecedente conforme al capítulo de regla. Esta forma de elegir se denominaba "por turno", correspondiendo el primero al padre mayor y después le siguieron los hermanos por antigüedad.

Otra de estas fiestas registradas en la documentación fue la de 1645, en el que las jóvenes elegidas por este patronato, previa visita de verificación de que la joven merecía recibir una dote por dos hermanos de la Casa de Misericordia de Sevilla, recibiendo un nombramiento de dote y una túnica blanca con la que harían la procesión el día de la fiesta del Dulce Nombre de María en ceremonia realizada en la iglesia de la Casa Pía. Después de haber cumplido con el ritual, el novio debía pedir licencia al padre mayor de la institución para casarse. ${ }^{25}$ Si contraía matrimonio sin haber pedido permiso perdía la dote, pues todo matrimonio después del Concilio de Trento debía ser público y con testigos. De esta manera esta dotación se hacía con el explícito propósito de propagar y hacer el acto de la boda, un evento público y hacerlo una costumbre entre los más pobres.

El proceso era el siguiente: primero, el cabildo en junta convocaba la fiesta al Dulce Nombre de María unos meses antes de su ejecución; luego, se ponían los edictos de manifestación del cumplimiento de la obligación de quince a treinta días en todas las parroquias, sitios públicos y alrededores de la ciudad de Sevilla, llamando a doncellas naturales de ella y sus arrabales, huérfanas de padre o de madre, que quisiesen postular a la fiesta que se había de celebrarse en el mes de septiembre al Dulcísimo Nombre de María Santísima en la iglesia de la Casa de Misericordia. Todas las pretendientas debían

${ }^{24}$ AGI, Contratación, 964 B, N.2, R.17, 1639. Bienes de difuntos: Alonso de Montalván. Autos sobre bienes de difuntos de Alonso de Montalbán.

${ }^{25}$ AHPS, Libro cabildo 4749 (1643-1649), 14/02/1645, f. 122v. Nombrada se le dio el vestido blanco. 
presentar las fes de sus bautismos, orfandad y pobreza. Los memoriales y papeles de las jóvenes propuestas por los hermanos de la Misericordia y sin proposición se remitían al cabildo con una memoria de sus nombres.

El número de doncellas a dotar dependía de las cuentas del patronado determinadas por la contaduría. Las dotadas eran elegidas por los hermanos de la hermandad que hubiesen cumplido sus obligaciones, las cuales eran asistir a los cabildos mensuales, asistir a los entierros de los miembros y cumplir con sus obligaciones encomendadas por el padre mayor, su superior.

\subsubsection{Elección y nombramiento de las doncellas que han de asistir a la fiesta del Dulcísimo Nombre de María}

En 1742, el cabildo se enfrentó a una duda en cuanto al nombramiento de las dotadas. ${ }^{26}$ En clausula testamentaria indicaba que debía ser un concurso público en el que cualquier joven podía presentarse si cumplía con los requisitos y de ellas se elegiría a las dieciocho dotadas. La otra manera era que cada hermano que hubiese cumplido con sus obligaciones nombraba a una dotada. Lo cierto es que las jóvenes nombradas por los hermanos debían presentarse a la convocatoria si querían beneficiarse de la dote. Entonces, ¿para qué convocar una convocatoria pública si los hermanos ya habían elegido a las afortunadas? Esta situación generó malestar y dudas y no se pusieron de acuerdo. Por eso, a veces, no solo había dieciocho nombradas a dote sino veintiséis, entre las cuales había jóvenes que no estaban entre las elegidas por los hermanos. De esta manera, dieciocho eran elegidas por los hermanos y las restantes de las que se presentaron por concurso público que no estaban avaladas por hermano alguno.

En cuanto a la elección de las dotadas, por ejemplo, en 1742, el informe y la memoria que contenía cincuenta y siete opositoras que pretendían ser nombradas para asistir a la fiesta del Dulcísimo Nombre de María Santísima en la iglesia de la Casa el 9 de septiembre de 1742, el padre mayor y los hermanos eligieron las dieciocho a quien tocó por turno, según lo acordado en la junta de voto decisivo de 23 de julio del año mencionado. Las elegidas dieron sus memoriales, certificados o documentos a los hermanos, en los que constaba ser naturales de esta ciudad, huérfanas y pobres quienes las remitieron con sus proposiciones.

La contaduría despachó dieciocho moldes o papeles impresos para que el padre mayor en nombre de este cabildo completase los vacíos con los nombres y datos de las jóvenes que nombrara en dote de 30 ducados. Y las dieciocho doncellas y caballeros hermanos que propusieron sus nombramientos, los aprobaron por la junta secreta como había sido costumbre. En 1742 se expresan en la forma siguiente:

El sr. conde del Águila como padre mayor propuso a doña Francisca Paula de Anaute.

\footnotetext{
26 AHPS, Libro cabildo 4762 (1741-1746) 13/07/1742. Junta de Hacienda. Por acuerdo del cabildo general de 1 de dicho mes y año se mandó formar esta junta con voto decisivo para resolver los dudas que se ofrecieren en cuanto a la Fiesta del Dulcísimo Nombre de María Santísima que se determinó celebrar en la iglesia de esta casa de la misericordia en el año de 1742 por la dotación de Alonso de Montalbán, consultándose primero por el padre mayor con un teólogo el si había de ser el nombramiento de las doncellas que han de asistir a dicha fiesta, proponiéndolas por turno los hermanos de esta casa o poniendo edictos para que las eligiese el cabildo y sobre el turno para diputados de la dicha fiesta.
} 
El sr. Conde de Villanueva propuso a María Rodríguez.

El sr. d. Gabriel Torres de Navarra propuso a María Ignacia.

El sr. d. Ignacio Chacón propuso a Ana Josefa Andrea.

El sr. d. Luis Ignacio de Conique propuso a Juana Josefa.

El sr. marqués de Villamarin propuso a Ana Francisca Nicolasa.

El sr. d. Pedro de Villaris propuso a Ana Petronila.

El sr. d. Francisco de Paiba Torres propuso a María Manuela de Guevara.

El sr. Francisco de Esquivel propuso a Bernarda Anselma.

El sr. d. Luis de Castilla y Guzmán propuso a doña Micaela de Perea.

El sr. d. Joseph Osorio de los Ríos propuso a Maria Nicolasa Pan y Agua.

El sr. D. Alonso Bexines de los Rios propuso a Cristobalina Ignacia de Castro

E. sr. d. Gaspar Fernández de Santillán propuso a Manuela de Pineda.

El sr. conde del Águila como hermano de esta casa por haber alcanzado el turno para elegir doncella, propuso a doña Eulalia María de la Concepción.

El sr. Conde de Mejorada propuso a doña María Cornejo.

El sr. d. Joseph de Armenta propuso a doña Catalina Josepha.

El sr. d. Juan de Saavedra propuso a María de San Pedro.

El sr. marqués de Vallehermoso propuso a Teresa María Josefa.

Estas fueron las 18 doncellas que habían de asistir a la referida fiesta el Dulcísimo Nombre de María, propuestas por los mencionados el padre mayor y los hermanos de la Casa de Misericordia que el cabildo había aprobado y nombrado.

De esta manera se observa que no respetaron la voluntad del testador de elegir a las dotadas en convocatoria pública sino que lo hicieron según voluntad de los hermanos de la cofradía. Así pues, según el testamento de Montalban,

"las jóvenes debían ser de buena vida y fama huérfanas de padre o madre, las cuales había de nombrar el cabildo de la Misericordia por votos, poniendo edictos para que lo supiesen y se presentaran, prefiriendo siempre a las más pobres". ${ }^{27}$

Esto generó problemas y reclamaciones de parte de la colectividad, pues muchas jóvenes se presentaban y gastaban dinero en constancias o fes de nacimiento y otros documentos. Por, ello, a las que no habían de ser elegidas por los hermanos al final sólo se les pidió que presentaran una solicitud de acceso a una dote del patronato. Eso explicaría por qué a veces se extiende el número de dotadas de dieciocho a veintiséis, con lo cual dotar a jóvenes presentadas por oposición.

Asimismo, en 1747, el padre mayor y veinticinco hermanos eligieron a las jóvenes y los diputados para la fiesta, tocando el turno a Joseph de Armenta y Juan de Saavedra quienes se encargaban del adorno de la iglesia y altares y, en cuanto al día en que se celebraría, sería el octavo del Dulcísimo Nombre de María. Y los referidos señores propusieron a las jóvenes que se habían presentado a la licitación pública para las veintiséis dotes.

\footnotetext{
${ }^{27}$ AHPS, Libro cabildo 4762 (1741-1746) 01/07/1742.
} 


\subsubsection{Aprobación de las dotadas}

El cabildo debía aprobar todas las proposiciones hechas por los hermanos y dar comisión al padre mayor para que lo confirmara, firmando los moldes de cada dotada en nombre del cabildo, el suyo y del hermano que la propuso para nombrarla. En ese mismo papel constaría la visita, reseña de la misma y la asistencia al casamiento. Después, se tomaban sus datos en el libro del secretario de cabildo, para recién formar comisión para la visita de la joven y de su casamiento.

Una vez determinado el número de jóvenes a desfilar, según informe que hacia la contaduría de la Misericordia, se sacaba una lista con sus señas y nombres de todas las doncellas candidatas a obtener un nombramiento de dote de ese patronato. Esas memorias se repartían entre los hermanos para que hicieran exhaustas diligencias en la averiguación del estado de vida o muerte en que se hallaban las nombradas. Los diputados, hermanos en pares, visitarían a las jóvenes para comprobar que cumplían con los requisitos. Realizadas todas estas diligencias, las que parecieren o averiguaren estar muertas y tener hermana o padre o madre que les heredara, según indicaba la fundación se les pagaría y la contaduría anotaría estos asientos. Las fallecidas que no dejaban personas que les heredaran, perderían estas dotes. ${ }^{28}$

El número de dotadas dependía de la renta. ${ }^{29} \mathrm{El}$ padre mayor y veinticinco hermanos eligieron a las jóvenes y a los diputados para esa fiesta, también determinaron que el día celebrado sería el octavo del Dulcísimo Nombre de María. La paga de las dotes era el Viernes Santo siguiente al casamiento, ${ }^{30}$ siempre y cuando procesionaran. Un requisito era que el novio debía pedir licencia antes de casarse con la dotada y los diputados asistirían a su matrimonio como testigos.

\subsubsection{Día de la fiesta}

La fiesta de Alonso Montalbán era el día del Dulce Nombre de María realizada en la iglesia de la Misericordia el 17 de septiembre, el sábado primero después de aquel día, el último día de la octava con víspera o cualquier día que lo decidiera el cabildo en forma justificada. ${ }^{31}$ Esta celebración comprendía un sermón por el cual el sacerdote recibía una limosna de 24 reales y se realizaba tal cual lo quería su fundador con todo el boato debido, con música, almuerzo, bebidas, fuegos artificiales, velas, palios, adornos, doncellas estrenando ropa nueva y blanca. Resultaba cara, por lo que restringieron los gastos desde 1742 .

\footnotetext{
${ }^{28}$ AHPS, Libro cabildo 4754, (1691-1700), 21/08/1695, f. 205r-206v.

${ }^{29}$ Así, en 1747 fueron entregadas veintiséis dotes, según lo acordado en los cabildos de 4 de junio y 2 de julio de aquel año.

${ }^{30}$ AHPS, Libro cabildo 4762 (1741-1746) 04/08/1743. En 1743, el padre mayor debía firmar los moldes donde constaban los nombres de las jóvenes propuestas para que asistieran en la Fiesta de María y los nombres de los hermanos que las propondrían. En cuanto a la visita, reseña y asistencia al casamiento tenía que hacerse en la misma forma que se hacía con las demás dotes de la Misericordia y su paga se hacia el Viernes Santo siguiente a su casamiento.

${ }^{31}$ AHPS, Libro cabildo 4763, (1746-1751), 06/08/1747. Actualmente, el Dulce Nombre de María se celebra el 12 de septiembre. AHPS, Libro cabildo 4763 (1746-1751) 06/08/1747, el día octavo del Dulcísimo Nombre de María que era el domingo 17 de septiembre de 1747.
} 
En el siglo XVI, esta fiesta era más generosa con el público asistente, con la presencia de dos clarines, con dulces (aleluyas, pebetes y pastillas) y refrescos para las doncellas y hermanos, familiares, incluso se le invitaba almuerzo al portero, cochero, colgadores y mozos que asistían a trabajar. El sacristán recibía limosnas. La iglesia se limpiaba y adornaba con colgaduras, los invitados procesionaban con velas de dos libras. Los hermanos recibían garrafas de fríos y agua clara, así como dulces, chocolate y pan.

En el templo se realizaba una procesión, asistiendo a ella el padre mayor y hermanos, a cada uno de los cuales se les había de dar una vela de dos libras con que asistiesen a los oficios y para aquel día se habían de vestir con ropa blanca a las dieciocho doncellas naturales de Sevilla y bautizadas en las parroquias de ella. Estas jóvenes recibirían un atuendo que debían llevar puesto entonces, que consistía en una saya, un jubón, un escapulario y un manto de anascote blanco y en el escapulario, un escudo con el nombre de María y una vela de media libra que llevarían en la procesión, asistiendo a los oficios. ${ }^{32} \mathrm{Y}$ una vez acabados se podían llevar los vestidos, quedando nombradas en una dote de 30 ducados cada una. Aquel año de 1704 fue la última vez que se usó este vestuario porque era muy caro. El costo del vestuario completo era de 176 maravedíes, comprendido en 12 varas y media de anascote blanco de 11 reales la vara y de dos varas y dos tercias de lienzo brabante para forro y ruedos a 43 reales cada una, además de 26 reales por su hechura. Por eso, desde aquel entonces fueron vestidas con hábitos de monjas, mantos de seda negros con vela de media libra y también el escudo.

La Casa acordó dar el importe del dinero del vestuario a las doncellas, las cuales debían confeccionar o mandar hacer los hábitos utilizados en 1704. Acabada la procesión se llevarían la vela y la cinta del escudo, pero éste se recogería para que sirviese en otra fiesta.

Como ya se ha indicado, los cofrades de la hermandad y sus hijos, en total 30, desfilaban con velas de a dos libras que recibían, encargándose la dotación del importe de los gastos generados por la procesión. La fiesta se hacía cantada, con música y fuegos artificiales, como toda celebración religiosa barroca para trasmitir a la colectividad poder, prestigio y unidad. La música provenía de la Catedral y tocaba mañana y tarde en la fiesta y procesión, aunque a veces se traían músicos de menor costo. La iglesia era adornada con colgados en los techos y tribunas, pero a comienzos del siglo XVIII, se determinó que sólo se colocara una colgadura en el cuerpo central y no en la capellanía mayor por estar estofada o adornada.

También se pagaron los derechos de la parroquia y capellanes que asistieron y en cuanto a los demás gastos de clarines, fuegos y otros que eran necesarios en la mencionada fiesta, se encargaba a los diputados que fuesen al menor costo posible.

En 1742 se redujeron los gastos en cuanto al pago del sermón, arreglo de la iglesia que se solían poner colgado desde los techos, tribunas y la capilla mayor y se entregaba el dinero a las doncellas para que ellas mismas se hicieran un hábito.

\footnotetext{
${ }^{32}$ PEREZ TORAL, 2017, p. 158. Anascote es una tela delgada de lana, asargada por ambos lados, usada para vestidos de mujeres, en algunas provincias de España usada en los siglos XVI al XVIII.
} 


\begin{tabular}{|l|l|}
\hline \multicolumn{2}{|c|}{ Gastos generados por la Fiesta del Dulce Nombre de María en $1742^{33}$} \\
\hline Música & 150 reales \\
\hline Limosna del sermón & 150 reales \\
\hline Colgadura solo en el cuerpo de la iglesia, por colgar y descolgar & 150 reales \\
\hline Velas de dos libras para los hermanos e hijos & $\begin{array}{l}\text { Décima de la } \\
\text { dotación }\end{array}$ \\
\hline Derechos de la parroquia y capellanes & $\begin{array}{l}\text { Décima de la } \\
\text { dotación }\end{array}$ \\
\hline Los fuegos y barriles & más de 100 reales \\
\hline Flores & 10 reales \\
\hline Dos clarines & 30 reales \\
\hline Sacristán & 120 reales \\
\hline Aleluyas, pebetes y pastillas & Ya no se daban \\
\hline Dulce y refresco a las doncellas & Ya no se daban \\
\hline $\begin{array}{l}\text { Refresco que se daba acabada la fiesta a los hermanos } \\
\text { comprendía 9 garrafas de fríos de 30 vasos cada una, y 3 de agua } \\
\text { clara. Y a 60 libras de bizcochos de dos géneros y 14 libras de } \\
\text { pañales, 6 libras de chocolate y el pan que pareciere }\end{array}$ & \begin{tabular}{l} 
No indica \\
\hline El almuerzo dado al portero, cochero, colgadores y sirvientes
\end{tabular} \\
\hline Limpieza de la parroquia & Ya no se daban \\
\hline
\end{tabular}

El día siguiente de la fiesta había de estar el Sacramento descubierto hasta que se acabaran los oficios con el adorno y cera necesaria.

\subsubsection{El casamiento de las doncellas: acto necesario para recibir la dote}

Las jóvenes eran nombradas, visitadas y realizaban la procesión, pero muchas no se casaban, pues no era fácil conseguir marido con las magras dotes que ofrecían a las jóvenes o porque fallecían y no lo comunicaban a la Misericordia. Las jóvenes tenían diez años para conseguir marido, ya que la intención del fundador era dotar a las doncellas que se iban a casar y no sólo nombrarlas. Sin embargo, algunas de ellas demoraban veinte, treinta y cuarenta años para conseguir marido, perjudicando a otras que teniendo próximos sus matrimonios pudieran llevar las dotes. Una cláusula del testamento del fundador disponía que, habiendo salido en procesión la doncella nombrada y muriendo antes de casarse, le diesen los 30 ducados de vellón de dote que tocaba a la hermana soltera casamentera y de no tenerla a su padre o a su madre y a falta de los mencionados, regresaría la limosna a la Misericordia. El día de su casamiento debía comunicarlo a la Misericordia para que se hallara presente un hermano que para ello el cabildo señalara. Una vez casada se le darían 30 ducados en vellón.

33 AHPS, Libro cabildo 4762 (1741-1746) 13/07/1742. Acuerdo tomado en la junta capitular de la Casa de Misericordia. 


\section{Evolución de la dotación de doncellas del patronato Montalbán}

A fines del siglo XVII, las rentas de la dotación de Alonso de Montalbán seguían siendo repartidas en cuatro partes, teniendo algunas de ellas sus fincas especiales. Según lo había dispuesto a través de su testamento.

Ninguna de las dos festividades tuvo continuidad en el tiempo. Ambas fueron interrumpidas por largos periodos al no haber acumulado suficiente dinero para llevarlos a cabo. De las dos, la primera en desaparecer fue la festividad del Sacro Santo Misterio de la Eucaristía en 1692.

La festividad del Dulcísimo Nombre de María Santísima no desapareció pero, ya tenía quince años que no era celebrada en la Misericordia a 1695, además las jóvenes demoraban mucho tiempo en recibir la dote desde que eran nombradas. La Misericordia había propuesto cien doncellas desde hacía años que ya habían salido en las procesiones anteriores, habiendo muchas que estaban escogidas a fin de 1691. El contador determinó que en los últimos ocho años se había pagado treinta y siete dotes de las cien nombradas y todavía quedaba de caudal para su disposición 92.877 maravedíes y los productos de lo que le pertenecía desde 1 de enero de 1692 hasta 1695 y considerándose el monto de las sesenta y tres dotes que faltaban de pagar sería de 201.555, 2 maravedíes.

El problema estaba en que muchas jóvenes no conseguían casarse. La Misericordia no quería pagar a las dotadas nombradas de más de diez años de espera, según lo dispuesto en los papeles entregados a las doncellas, pues esto ocasionaría muchos problemas para las futuras. La intención de los fundadores era principalmente entregar las dotes a las doncellas que se iban a casar y no solo nombrarlas. Algunas de estas mujeres tenían entre veinte y cuarenta años sin casarse desvirtuando con ello no solo la intención de los fundadores sino también el fin con que se fundaron. Resultaba en perjuicio de otras que teniendo próximos sus matrimonios pudieran llevar las dotes.

Uno de los hermanos recomendó que se nombraran cada dos años y las doncellas se casasen dentro de los diez años, en caso contrario perderían el derecho de tal nombramiento. De no ejecutarse así, sucederían los embargos que estaban experimentando. Sin embargo en 1695, el patronato tenía sesenta y tres doncellas nombradas que no se habían casado. Algunas lo estaban desde antes de 1645. Muchas posiblemente muertas en la gran peste de $1649 .{ }^{34}$ En este caso, según dispuesto en la cláusula del testamento de fundador que habiendo salido en procesión la doncella nombrada y muriendo antes de casarse se le diesen los 30 ducados de vellón de dote que le tocaba a la hermana doncella y de no tenerla a su padre o a su madre y a falta de los mencionadas regresaría la limosna al cabildo de la Misericordia. Desde que se fundó la mencionada dotación no se tenía noticia en la contaduría de haberse así ejecutado en 1695.

La Misericordia afrontaba varios problemas en la administración de este patronato:

\footnotetext{
${ }^{34}$ CARMONA GARCÍA, 1993, p.200. Aproximadamente 60.000 personas murieron. Quizá sobrellevar un matrimonio se antojaba por aquel entonces difícil; en especial para las mujeres.
} 
1) Uno de ellos era la falta de noticias de las muertes de las doncellas nombradas para así ejecutar exactamente la voluntad del fundador, regresando la dote a la institución y volver a usarse en otra joven. Ante esta situación, la Misericordia ordenó publicar edictos en todas las partes públicas de la ciudad de Sevilla, haciendo relación de lo contenido en dicha cláusula para que dentro del término de una fecha aparecieran en la Misericordia cualesquier personas que tuviese derecho a cobrar estas dotes. Si aparecían y lo justificaban recibían la dote, en caso contrario se daba por perdido y anotado en los libros.

2) La voluntad del testador de que los hermanos eligieran a las doncellas nombradas previa convocatoria pública, no se hacía sino que cada hermano elegia a sus doncellas, las que debían presentarse previamente a la convocatoria. Desde 1640 se hacía de esta manera y se continuó alternado a veces ambos sistemas, según cabildo extraordinario de 21 de agosto de 1695. Antes del receso de esta fiesta en 1704 no había constancia escrita si se continuaron dichos edictos y solo sí que los nombramientos se hicieron en la misma forma de turno.

Los edictos generaban expectativa en la población por las necesidades que tenía la gente pobre, por lo que se temía que un gran número de doncellas se presentara a la convocatoria, necesitando para ello sacar las fes de sus bautismos, pobreza y orfandad. Dichos documentos originaban gastos, quedando defraudadas las que no alcanzaban un nombramiento. Un pretexto para anular la convocatoria pública a través de edictos para que solo nombraran según proposición de los hermanos.

En 1742, este problema no resuelto se llevó a la consulta al reverendo padre maestro Nicolás de Estrada de la compañía de Jesús quien dio su parecer en 11 de julio de aquel año, diciendo:

"ser de sentir deberse observar lo acordado en el cabildo de 1 de julio de 1640 de manera que el cabido vote los 18 dotes proponiendo los hermanos por turno y orden de antigüedad uno cada uno y precediendo los edictos como en la cláusula de la fundación se previene y manda. $\mathrm{Y}$ en cuanto al inconveniente que se propuso del gasto que resulta a las doncellas en el costeo de certificaciones dijo se evitaría fácilmente si se hacía correr la voz de no ser necesario que las pretendientes presentasen en la contaduría tales papeles mandando que en ella no se reciban y dejando a cargo de los hermanos que han de proponer justificar las calidades de sus ahijadas con los papeles que se requieren y el fundador manda". ${ }^{35}$

3) En el caso de la fiesta del Sacro Santo Misterio y la del Dulcísimo Nombre de María, el testador dispuso que se hicieran celebraciones siempre que cada uno de los hermanos que asistiere en ellos recibiera una vela de dos libras y empleara el órgano o chirimías o ambas cosas. Sin embargo, no podían hacer exceso de música en la iglesia mayor ni fuego ni que el adorno y colgado de la iglesia fuera tan excesivo que se gastara mucho, ni tampoco que se diesen velas de a dos libras a los caballeros, sucesores de los hermanos y demás hijos como se les estilaba dar. Si sobraba algo se daría 50 ducados a los venerables y para dorar al retablo. Y en cuanto a la fiesta de las doncellas se haría

\footnotetext{
${ }^{35}$ AHPS, Libro cabildo 4762 (1741-1746) 01/07/1742.
} 
con la solemnidad necesaria. Se realizaba también una fiesta para San José y otra para el fundador $\mathrm{y}$, si todavía excediese en mantos de lana para pobres.

Tal cual indica la documentación:

La fiesta del Dulcísimo Nombre de María era celebrada en el día de su octava en 1695 y con el mismo culto gasto y lustre como siempre se había hecho y con la asistencia y nombramiento de las dieciocho doncellas que disponía el fundador a las cuales se les daba el vestuario y dote ordinaria, las cuales eran nombradas por los hermanos por turno como siempre se había hecho estando advertida la contaduría en las demás festividades y nombramientos de doncellas que adelante se hicieren. $\mathrm{Y}$ en cuanto el costo de dicha fiesta se hacía cantada con la música de la iglesia, fuegos y demás gastos, cargada a la dotación. No hubiere exceso en cuanto a la distribución de las velas de a dos libras que se daban a los hermanos y sus hijos hasta una cantidad de 30. Se pusieron edictos por 30 días para que fuese público y notorio a las partes interesadas el derecho que tenía a las dotes y el cabildo cumpliese exactamente con su obligación siendo esta manifestación pública y para más satisfacción se pusiese en todas las parroquias y sitios públicos de la ciudad de Sevilla y sus arrabales. La contaduría sacaba una lista con señas y nombres de todas las doncellas nombradas en este patronato y por pagar, las cuales memorias se repartían entre los hermanos para que hicieran exhaustas diligencias en la averiguación del estado de vida o muerte en que se hallaban las nombradas y de las que fueran muertas las hermanas doncellas que hubiere o sus padres o madres para que se le noticiaran del derecho que tenían a estos dotes. Realizadas todas estas diligencias las que parecieren o averiguaren estar muertas y tener hermana o padre o madre que les heredara según indicaba la fundación estas dotes se les pagara enteramente y la contaduría anotara estos asientos. Las fallecidas que no dejaban personas que les heredaran se perderían estas dotes. Así y todo las nombradas que se dudaba su destino si estaban muertas o vivas entonces de aquellas se haría una lista que se tuviera presente para que en cualquier momento que pareciera las tales nombradas o sus herederos se les diese la dote. ${ }^{36}$

De esta manera, en la dotación de Montalbán si moría la doncella dotada y no tenía hermana la dote la podía recibir la madre. Se debía comprobar y se entregaba la dote de 30 ducados. ${ }^{37}$

Antes de realizarse cualquier fiesta religiosa, la contaduría debía indicar el estado económico de este patronato y según ello, determinar el número de doncellas a dotar y el número de curas a festejar. En el año de 1697, el informe realizado por la contaduría en cuanto al estado del legado de Alonso de Montalbán sobre las festividades del Santísimo Sacramento en la cual se vestían dieciocho sacerdotes y asimismo en la del Dulce Nombre de María que se vestían y dotaban dieciocho doncellas aconsejó al cabildo de la Misericordia realizar las fiestas aquel año, lo que fue acordado. La decisión de hacer las fiestas fue tardía por lo que no se había hecho en sus fechas la del Santísimo Sacramento, llevándose a cabo el día 8 de septiembre y la del Dulce Nombre el día 9 de ese mes. La liberación de presos se ejecutaría el día que señalara el padre mayor que sería en Navidad cuando se decidiera según suertes (urna) los diputados que llevarían a cabo aquella tarea.

\footnotetext{
${ }^{36}$ AHPS, Libro cabildo 4754, 21/08/1695, f.205r-206v.

${ }^{37}$ AHPS, Libro cabildo 4755, 01/08/1706, s/f.
} 
Se organizaban comisiones para llevar a cabo las fiestas del Santísimo Sacramento y el Dulce Nombre de María, avisando la contaduría a los hermanos que les tocaba por turno este cuidado.

Esta fiesta del Nombre de María se celebró hasta el año de 1704 que fue la última con la misma solemnidad que la del Santísimo Sacramento en que se vestían 18 sacerdotes y después se suspendió su cumplimiento. La causa de la suspensión fue debido a las deudas, empeños de la renta y por la falta "de cabimiento de los juros pertenecientes a dicha disposición que compone la mayor parte de su renta". ${ }^{38} \mathrm{Se}$ suspendió hasta que hubiese caudal suficiente. Aquel año de 1704 se gastaron en la fiesta de doncellas 11.810 maravedíes. De ella, dieciocho a razón de 30 ducados de oro cada uno, es decir 5.955 mrs y los 5.855 restantes en los gastos de la fiesta y vestidos de las doncellas.

Esta celebración se volvería a celebrar teniendo expuesto al sacramento, asistiendo a ella 18 doncellas, por acuerdo de la junta de voto decisivo que fue confirmado en el cabildo de 8 de noviembre de 1733, momento en el que se mandaron publicar edictos con término de 15 días, y cumplidos se apelase a cabildo para elegir las que habían de ser nombradas para que luego se celebrase una fiesta con el numero de 18, nombrándolas el cabildo y precediendo edictos para ello.

Los gastos de la fiesta de 1742 fueron drásticamente reducidos incluso no se respetó el día de su celebración el 17 de septiembre porque chocaba con otra festividad sevillana.

"La Hermandad de Nuestra Señora de las Maravillas sita en la parroquial de Juan de la Palma hace novenario a la Natividad de Nuestra Señora y el ultimo día que es el referido 16 de septiembre tiene procesión por las calles en donde era preciso se asistiese por la más de la gente y muchos de los hermanos de esta casa y sus hijos se encontraba el reparo de que la de esta dicha casa no tuviese la asistencia y lucimiento que era debido". ${ }^{39}$

En el cabildo de la Casa de Misericordia se pidió que la fiesta de María se hiciera el 9 de septiembre y se determinó que se realizara el día octavo de dicha festividad 16 de septiembre, pero fue cambiada para el 9 de aquel mes para no perjudicar a esta fiesta con la de Nuestra Señora de las Maravillas de la iglesia de San Juan de la Palma. ${ }^{40}$ Esta celebración o conmemoración a María coincidía con otras similares en Sevilla y resultaba dificultoso encontrar colgaduras para arreglar la iglesia.

"Esta festividad de Nuestra Señora es en tiempo que en distintas partes de esta ciudad se hacen octavarios y novenarios colgando sus iglesias. Era muy dificultoso a los Sres. diputados encontrar colgaduras decentes amas de ser muy pocas las que han quedado en esta dicha ciudad se confirió largamente sobre ello como asimismo el perjuicio que en dicho colgado recibió la iglesia así con los golpes de las escaleras y clavos que se ponían en las cornisas y que dejándose de colgar se evitaba este daño y de esto resultaba beneficio a la misma fiesta pues como se expresa en el acuerdo de la citada junta de voto decisivo no alcanza su renta anualmente para cumplirla por cuya razón se

\footnotetext{
${ }^{38}$ AHPS, Libro cabildo 4762, 1/07/1742.

${ }^{39}$ AHPS, Libro cabildo 4762,1/09/1742.

${ }^{40}$ AHPS, Libro cabildo 4762,1/09/1742.
} 
mandaron moderar los gastos sin faltar a lo preciso. Por todo lo cual se acordó de conformidad por esta junta de hacienda proponer al cabildo el que así en esta fiesta de María que se ha de celebrar en este año y para adelante como en el Sacramento no se cuelgue dicha iglesia". ${ }^{41}$

El 4 de diciembre de 1791, la contaduría informó que se había hecho el repartimiento de las 36 dotes de la dotación de Alonso de Montalbán para la fiesta del Dulce Nombre de María, según lo acordado en el cabildo del 6 de noviembre por el padre mayor que firmaba el molde de todas. ${ }^{42}$ El 2 de noviembre de 1792 se nombraron a 36 doncellas para el patronato Montalbán. ${ }^{43}$

La procesion del Dulce Nombre de María era un ritual practicado en la Casa Pía de la Misericordia a pedido de un patronato que lo dotó para ello con una generosa renta. La característica de esta procesión era el desfile en blanco de las dotadas cubiertas por un manto del mismo color.

"Y expresándose en la citada cláusula que a las dichas doncellas se les diese para que trajesen puesto el día de la fiesta saya, jubón, escapulario y manto de anascote blanco y en el escapulario un escudo con el nombre de María y una vela de media libra que llevaran en la procesión y acabado los oficios se llevasen los vestidos y quedasen nombradas en una dote de 30 ducados cada una". ${ }^{44}$

Esta práctica que se dio en Sevilla y otros lugares de la Monarquia Hispánica y se mantiene aún, por ejemplo, en un pueblo polaco, en Kalwaria Paclawska donde la procesión se realiza acompañada de la imagen de María yaciente en dimensiones humanas. ${ }^{45}$ Sin embargo, esta procesión se realiza en aquel lugar el 12 de agosto de cada año durante la Misa de celebración de la Asunción de María. En el Hospital del Pozo Santo de Sevilla que fue administrada por la Casa Pía u Hospital de la Misericordia también se encuentra una virgen de estas características, la conocida Virgen del Tránsito. Habría que preguntarse si alguna vez fue usada para una procesión de estas características. ${ }^{46}$

\begin{tabular}{|l|l|}
\hline \multicolumn{2}{|l|}{ Fiestas del patronato de Montalbán en la Casa de Misericordia de Sevilla } \\
\hline Fiesta Santísimo sacramento & Fiesta Dulce Nombre de María \\
\hline 1640 & 1640 \\
\hline 1645 & 1645 \\
\hline 1649 la gran peste & 1649 la gran peste \\
\hline
\end{tabular}

\footnotetext{
${ }^{41}$ AHPS, Libro cabildo 4762,1/09/1742.

${ }^{42}$ AHPS. Libro cabildo 4770(1786-1797) 04/12/1791, f. 198v- 199v.

${ }^{43}$ AHPS. Libro cabildo 4770(1786-1797) 02/11/1792, f. 252v- 253v.

${ }^{44}$ AHPS, Libro cabildo 4762, (1741-1746), 01/07/1742.

${ }^{45}$ ORTH, 2005, pp.1-31.

${ }^{46}$ P. E. RIVASPLATA VARILLAS. "La activa participación de las Madres Mayores del Hospital del Santo Cristo de los Dolores (Pozo Santo) bajo la administración dela Hermandad de la Misericordia de Sevilla”, en Cultura de los Cuidados, n47, p. 128.

47 AHPS. Libro cabildo 4755, (1700-1707) 03/08/1704, s/f; AHPS. Libro cabildo 4762, (1741-1746), 04/08/1743; AHPS. Libro cabildo 4763, (1746-1751), 02/07/1747, f.50r; AHPS. Libro cabildo 4770, (1786-1797), 02/11/1792, f. 252v- 253v.
} 


\begin{tabular}{|l|l|}
\hline & 1680 \\
\hline 1691 (pocas rentas) & 15 años sin realizarse \\
\hline 1692 (pocas rentas) & 1695 \\
\hline $1697(18$ curas $)$ & 1697 (18 dotadas) \\
\hline & No se dieron dotes \\
\hline $1704(18$ curas $)$ & $1704(18$ doncellas $)$ y liberación de presos \\
\hline 20 años sin realizarse & 1706 doncellas \\
\hline 1733 & \\
\hline 1740 & \\
\hline 1742 & 1742 \\
\hline & $1743(18$ dotadas $)$ \\
\hline & 1747 (26 dotadas) \\
\hline & $1791(36$ dotadas $)$ \\
\hline & $1792(36$ dotadas $)$ \\
\hline
\end{tabular}

En cuanto a los rituales llevados a cabo durante las procesiones de doncellas dotadas y del Santísimo Sacramento en la Casa de Misericordia de Sevilla se encuentran la entrega de una medalla a los religiosos, hincados de rodillas los hermanos de la Misericordia para que los sacerdotes las tomasen con sus manos y se las pusieran al cuello, las debían llevar puestas a la tarde para la asistencia de la procesión que se ejecutaba. Los diputados entregaban también una medalla a las dotadas pero sin arrodillarse en la festividad de las doncellas. Los diputados no se debían hincar de rodillas, pues eso solo se debía ejecutar con el sacerdote. Este acuerdo se llevaba a cabo inviolablemente en todas las celebraciones, sin que se pudiese renovar ni alterar cosa alguna en contra de él, si no fuera llamando a cabildo expresamente para este efecto y que hallaran al menos veinte hermanos. ${ }^{48}$ Otro ritual era que las dotadas debían ir vestidas con hábitos blancos a la procesión y los sacerdotes hábitos nuevos. ${ }^{49}$

En el siglo XVIII, la realización de la fiesta de los sacerdotes, la celebración del Dulce Nombre de María y la liberación de presos fueron ejecutadas con la solemnidad acostumbrada porque había caudal en la dotación de Alonso de Montalbán. ${ }^{50} \mathrm{Si}$ había dinero primero se ejecuta la fiesta de doncellas, luego la liberación de presos y, finalmente, la festividad de los sacerdotes. ${ }^{51}$

\footnotetext{
${ }^{48}$ AHPS, Libro cabildo 4754, 05/08/1697, f. 238r-239r.

${ }^{49}$ AHPS, Libro cabildo 4755, 03/08/1704, s/f

${ }^{50}$ AHPS, Libro cabildo 4755, 05/07/1704, s/f.

51 AHPS, Libro cabildo 4755, 06/09 /1704, s/f. En 1704, la contaduría ajustó la dotación de Alonso de Montalbán por lo que tocaba a la fiesta de los Sacerdotes y habiéndose ejecutado la liberación de presos que el cabildo mando, reconoció que sobraba 5 mil y tantos reales. Este caudal era suficiente para hacer la fiesta de los sacerdotes y se acordó de conformidad proponer al cabildo ejecutarla.
} 


\subsection{Casos particulares}

Aunque este patronato fue creado para ayudar a jóvenes pobres a contraer matrimonio, algunas no lograron casarse a pesar de haber obtenido una dote. Fue el caso de una anciana nombrada a dote que no se había casado, por lo que solicitó la entrega del dinero como limosna para su vejez. En 1725, Ana María de Sandoval, vecina de Sevilla, estaba nombrada a una dote de 30 ducados, había salido en procesión en la fiesta del Dulcísimo Nombre de María con un vestido entregado por el patronato de Alonso de Montalbán en 1675; sin embargo, no había podido tomar estado. Tenía más de 66 años y sufría de achaques propios de su edad. Vivía en compañía de una hermana viuda con más de ochenta años:

"y no siendo capaz de tomar estado, así por sus achaques como por sus muchos años y necesidad y que teniendo noticia que otras nombradas en dotes de dicha dotación que habiendo salido en la procesión y hállense en crecida edad y enfermas se había compadecido de ellas este cabildo mándeles pagar los 30 ducados de las dotes por la franqueza que da el fundador y que constando de las que padecía informe el señor don Gerónimo de Céspedes conde de Villanueva, hermano de esta casa". ${ }^{52}$

El padre mayor debía informarse de las condiciones impuestas por el fundador de la dotación y, conforme a ella, determinar lo que el cabildo debía hacer. No se le concedió porque el dinero dotal tenía un fin concreto que era casar a doncellas pobres.

Menos jóvenes se casaban por la crisis económica y existencial. Una consecuencia que asumieron las siguientes generaciones a la gran peste de 1649. Cada vez más doncellas desistían en casarse. El matrimonio ya no representaba un lugar seguro para sobrevivir, agudizado por la pésima situación económica que fue acrecentándose en el siglo XVIII. En 1706, el desistimiento de una dote que estaba dada a Alejandra Cristobalina de Amores por nombramiento de Diego de Payva y Torres de 30 ducados y un vestido de la dotación de Alonso de Montalbán, y por tener la fundación la condición de que si habiendo salido en la procesión la nombrada muriese sin tomar estado y dejara hermana doncella se le diese la dote. Sin embargo, desistió también su hermana Ana Marcela y el cabildo de la Misericordia lo aceptó, dándose otra oportunidad al hermano Diego de Payva para que nombrara a otra joven. ${ }^{53}$ Los hermanos de la cofradía si cumplían con sus deberes que eran asistir a los cabildos, a los entierros de hermanos y a las visitas de las pretendientes podían elegir a las dotadas.

En 1720, una joven llamada Lucia de la Fe participó en la procesión del Dulcísimo Nombre de María en la Iglesia de la Misericordia, obtuvo un nombramiento de dote en 1697, pero no se había casado y no quiso hacerlo porque estaba muy enferma del corazón, tal como indicaba en la certificación que presentó el médico Isidro de Bobadilla. No tenía padres y sólo una media hermana casada. Solicitó la entrega de su dote porque no tenía descendientes directos y porque existía un precedente de concesión en la Casa de Misericordia. La institución accedió, porque ya existía un precedente. Según información dada por la contaduría, en el cabildo del 6 de enero de

\footnotetext{
52 AHPS, Libro cabildo 4758 (1723-1727) 07/10/1725.

${ }^{53}$ AHPS, Libro cabildo 4755 (1700-1707), 07/02/1706, s/f.
} 
1704, mandó pagar a Tomasa Estefanía de Morales su dote de 30 ducados porque no tenía hermana soltera, ni padres, presentando solo fe del médico de estar enferma. ${ }^{54}$

Igualmente, una joven que ya había hecho procesión de dotadas, enfermó del pecho y cedió sus derechos en su hermana quien también desistió de la dote y pidió que fuese utilizado el dinero como ayuda de la hermana enferma. En 1721, Josefa María de Torres, vecina de la ciudad de Sevilla y viuda de Gerónimo Damián, tenía dos hijas únicas, Petronila y Luisa. La primera fue nombrada a una dote de 30 ducados y un vestido de la dotación de Alonso de Montalbán con la que salió en procesión el año de 1695. No pudo casarse porque le había dado un cáncer de mama, padeciendo grandes necesidades por su pobreza. Y desistió de su dote a favor de su hermana Luisa que, también, hizo lo mismo. La renuncia de ambas hermanas por escribano público se realizó para que el hospital entregara los 30 ducados para el sustento de la enferma. La casa lo aceptó y entregó la dote a modo de limosna a la enferma dotada, a pesar de tener hermana soltera. ${ }^{55}$ En este punto había que aclarar que la sociedad consideraba que el matrimonio era el estado de la mujer para cumplir su papel de madre, esposa y sentirse protegida en el seno de su hogar, ya que la soltería o el celibato se consideraban como situaciones de desventaja y de abandono. ${ }^{56}$ De ahí la necesidad de incluir la ayuda a la hermana soltera para facilitar su búsqueda de encontrar marido y así "remediarla".

\section{Conclusiones}

Este trabajo trata de fiestas barrocas olvidadas y que es necesario rescatar para que se tengan presente en la actualidad, que pervivieron en la Modernidad por muchos años. Agrupaciones de personas agrupadas en hermandades y patronatos ayudaron a paliar la pobreza de las personas que vivían en honra y buena fama, pues esos eran los requisitos exigidos para ser merecedores a uno de estos reconocimientos. En cuanto a las dotes a matrimonio, los legados testamentarios que la Iglesia a través de sus diversas instituciones canalizaba, se incrementaron a partir del Concilio de Trento (1545 y 1563). Dotes de cantidad establecida que con el pasar del tiempo dejaron de ser atractivas en el mercado matrimonial y no lograron su objetivo que era llevar al matrimonio a jóvenes pobres honestas.

La Casa de la Misericordia de Sevilla realizaba anualmente a pedido de uno de sus donantes, Alonso de Montalbán, unas fiestas de celebración a Cristo y a la Virgen María, donde reconocían públicamente como ejemplos a imitar a sacerdotes honrados, viejos y pobres y muchachas vírgenes y virtuosas. Estas celebraciones reflejaban una característica intrínseca de las casas de Misericordia que era reconocer públicamente a las personas con virtudes, tanto del donante, como de los que recibían el reconocimiento a modo de limosna. Es decir, esta institución canalizaba esta ayuda solo al que se lo merecía. De ahí que los hermanos emplearan tanto tiempo en comprobar y averiguar que las personas a quienes iba dirigida la ayuda eran dignas de premiar. Por lo que a

\footnotetext{
${ }^{54}$ AHPS, Libro cabildo 4757, (1719-1723), 17/03/1720.

${ }_{55}$ AHPS, Libro cabildo 4757, (1719-1723), 06/07/1721.

${ }^{56}$ LORENZO MONTERRUBIO, 2015, p.43.
} 
veces, contra la voluntad del donante de ser un acto abierto, la hermandad utilizaba esta dotación, premiando a los hermanos que cumpliesen con sus obligaciones, asignándoles el poder elegir a las jóvenes que recibirían la dote. Este patronato permitió que se celebrasen estas festividades por más de un siglo y medio, con interrupciones, y se acabaron cuando sus rentas mermaron por las inestabilidades económicas generalizadas que sacudieron a la monarquía española en la Edad Moderna.

La casa pía de Misericordia realizó la primera procesión de dotadas en la Fiesta del Dulcísimo Nombre de María en 1640, de manera bastante tardía, cuando Sevilla ya tenía la costumbre bastante arraigada en realizar estas procesiones públicas de entrega de dotes a doncellas pobres a nombre de la virginidad de María, siendo la más famosa la Capilla de las Doncellas de la Hermandad de la Anunciación de la Catedral Hispalense desde el siglo XVI. En la Misericordia, cada dotada recibía 30 ducados gratuitamente. Las nombradas a esta dote eran visitadas por un miembro de la hermandad, después iría a procesión el día señalado. Esta ceremonia le daba prestigio a los ojos del pueblo sevillano. Una vez casadas ante testigos enviados por el hospital, los esposos recibirían la dote, previa entrega de carta dotal. Cabe resaltar que otras ciudades de la Metrópoli española e indiana, a donde fueron transportadas estas procesiones, las realizaban principalmente en sus catedrales, pero también en iglesias, pues estaba generalizada la ayuda de la sociedad a la mujer virtuosa y honrada, canalizada a través de la Iglesia.

En la Edad Moderna, la Virgen María se convirtió en el modelo del discurso patriarcal cristiano que debían imitar las mujeres, con la que se debían identificar para controlar las cualidades negativas atribuidas a su propia naturaleza. La Iglesia ayudada por la sociedad con sus donaciones testamentarias a través de patronatos fundados para tal fin, incentivaba que la mujer sobre todo pobre mirase a la Virgen María como el nuevo espejo en la cual verse reflejadas, pues al seguir su humildad, discreción y pureza, lograba dignidad y respecto en el mundo patriarcal en el cual estaban inmersas. Para así, alejar el estigma medieval de verlas como pecadoras y causantes de pecado, como hijas de Eva.

Esta investigación trato de develar el proceso de la entrega de dotes desde la convocatoria pública, el nombramiento, la procesión, la entrega de la carta dotal y la dote una vez que las jóvenes se casaran con la presencia de algún miembro de la Misericordia como testigo. La festividad en sí era pomposa, alegre, festiva, bulliciosa y con un ritual a seguir que incluía misa, procesión de las dotadas acompañadas por la hermandad y sus familiares con velones, incienso y música e incluso tentempiés para atraer la mayor cantidad de feligreses y fuesen testigos de la festividad. La presencia de público era importantísimo en estas actividades religiosos para que la mayor cantidad de gente fuese testigo del acto, incluso se posponían si competían con otras procesiones de otras iglesias vecinas, que pudiesen restar público a la procesión de las dotadas.

La Casa de la Misericordia asumió esta dotación por más de 150 años, pero paulatinamente se fue dejando de lado, perdiéndose en el olvido, sin ninguna continuidad, una vez que cayeron sus rentas en bancarrota, golpeadas por la galopante inflación, resultando más difícil conseguir marido por las magras cantidades ofrecidas y 
por el cambio de mentalidades que se estaba operando en la sociedad que era cada vez más laica y pragmática.

\section{REFERENCIAS BIBLIOGRÁFICAS}

ALBARDONEDO FREIRE, Antonio, "La iglesia nueva del hospital de la Misericordia. Un proyecto de Asensio de Maeda con importantes colaboraciones (15951606)", Laboratorio de Arte, 2003, pp. 67-105.

ATIENZA LÓPEZ, Ángela, "La apropiación de patronatos conventuales por nobles y oligarcas en la España Moderna", Investigaciones Históricas, Universidad de Valladolid, número 28, 2008, pp. 79-116.

BIRRIEL SALCEDO, Margarita, "Las mujeres en la frontera del Poniente granadino", Las mujeres en la Historia. Itinerarios por la provincia de Granada, Granada, Universidad de Granada, 2012.

CARMONA GARCÍA, Juan Ignacio, El extenso mundo de la pobreza: la otra cara de la Sevilla Imperial, Sevilla, Ayuntamiento de Sevilla, Servicio de Publicaciones, 1993.

CONGREGACIÓN DE LA CASA DE LA MISERICORDIA, Regla de la Congregación de la Misericordia de Sevilla, Sevilla, En casa de Clemente Hidalgo, 1599.

CONGREGACIÓN DE LA MISERICORDIA, Regla de los hermanos de la Misericordia de la ciudad de Sevilla, Sevilla, por Alonso Rodríguez Gamarra, 1622.

CUÉLLAR ARRABALÍN, María Trinidad, "Testamento femenino malagueño. Siglo XVII", Pilar Ballarín y Teresa Ortiz (eds.), La Mujer en Andalucía. Primer encuentro interdisciplinar de estudios de la mujer, Granada, Universidad de Granada, 1990, pp. 237-255.

ESCALERA PÉREZ, Reyes, "La fiesta barroca como portavoz de la emblemática: el caso de Sevilla", en Rafael Zafra Molina, José Javier Azanza López, (Coords), Emblemática trascendente: hermenéutica de la imagen, iconología del texto, Universidad de Navarra, 2011. pp. 273-285.

GARCÍA BERNAL, José Jaime, El fausto público en la España de las Austrias, Sevilla, Universidad de Sevilla, Secretariado de Publicaciones, 2006.

GIMÉNEZ MUÑOZ, María del Carmen, "Breve historia de los establecimientos benéficos en Sevilla desde su fundación hasta 1900", Hispania Nova. Revista de Historia Contemporánea, Número 6, 2006, pp. 1-27.

HERMANDAD DE LA ANUNCIACIÓN DE NUESTRA SEÑORA DE SEVILLA, Regla o Estatuto de la Congregación y Capilla de la Anunciación de Nuestra Señora, que llaman de las Doncellas en la Santa Iglesia Metropolitana y Patriarcal de Sevilla, Sevilla, por Juan Francisco de Blas, 1715.

LATORRE CIRIA, José Manuel, "Las obras pías como camino de salvación: el obispado de Albarracín (siglo XVII)", en Studia Historica. Historia Moderna, número 37, 2015, pp.183-210.

LOBO DE ARAÚJO, María Marta, “As misericórdias portuguesas enquanto palcos de sociabilidades no século XVIII", História: Questões \& Debates, Curitiba, Editora Universidade Federal do Paraná, número 45, 2006, pp. 155-176.

LOBO DE ARAÚJO, María Marta, "O mundo dos mortos no quotidiano dos vivos: celebrar a morte nas Misericórdias portuguesas da época moderna", Comunicação \& Cultura, número 10, 2010, pp. 101-114. 
LORENZO MONTERRUBIO, Carmen, Arte suntuario en los ajuares domésticos. La dote matrimonial en Pachuca, siglo XVII, Pachuca de Soto, Universidad Autónoma del Estado de Hidalgo, 2015.

MÁRQUEZ DE LA PLATA Y FERRÁNDIZ, Vicenta María, Mujeres Renacentistas en la corta de Isabel la Católica, Madrid, Editorial Castalia, 2005.

MORELL PEGUERO, Blanca, Mercaderes y artesanos en el Sevilla del descubrimiento, Sevilla, Diputación Provincial, 1986.

ORTEGA LÓPEZ, Margarita, "El periodo barroco (1565-1700)", Historia de las Mujeres en España, Madrid, Editorial Síntesis, 1997, pp. 249-344.

PÉREZ TORAL, Marta, "El léxico de tejidos en inventarios notariales del siglo XVII", Revista de Lexicografía, XXIII, 2017, pp. 157-184.

PERRY, Mary Elizabeth, Hampa y sociedad en la Sevilla del Siglo de Oro, Sevilla, Fundación Focus Abengoa, 2012.

ORTH, Maureen, "María. La mujer más poderosa del mundo", National Geographic, diciembre, 2005, pp.1-31.

RIVASPLATA VARILLAS, Paula Ermila, "Las madres del bien morir del hospital de las Cinco Llagas de Sevilla en el Antiguo Régimen", Erebea. Revista de Humanidades y Ciencias Humanas, Universidad de Huelva, 2014, número 4, 2014, pp. 81-118.

RIVASPLATA VARILLAS, Paula Ermila, "La activa participación de las Madres Mayores del Hospital del Santo Cristo de los Dolores (Pozo Santo) bajo la administración dela Hermandad de la Misericordia de Sevilla", Cultura de los Cuidados, número 47, 2017, pp.110-128. 